\title{
The volcanic rock grinding stones from Selinunte, Sicily ( I taly): Archaeological evidence and geochemical provenance analyses
}

\author{
Christoph Schwall and Tatjana M. Gluhak
}

\begin{abstract}
This study is based on the assemblage of grinding stones from the Greek colony of Selinunte in Sicily. Most were brought to light in well stratified contexts dating to the 6th century BC making them ideal subjects for research on the development of early milling techniques. In addition to saddle querns, Selinunte has Olynthus mills and mills driven by rotary motion were discovered in previous excavations that are also representative of advances in milling technology. The Selinunte assemblage can be compared to contemporary mills from elsewhere throughout the Mediterranean Basin. Based on these comparisons, we suggest a saddle type of mill model comprising of a boat-shaped upper stone and a roughly rectangular-shaped lower stone as a precursor of the Olynthus mill. The sources of the rock point to mainland Sicily, the Aeolian Islands and perhaps from the Aegean Islands bolstering the supposed importance of this coastal settlement as a centre of trade in the central Mediterranean.
\end{abstract}

Keywords: Selinunte, grinding stones, saddle querns, Olynthus mills, rotary motion, provenance, volcanic rocks

Christoph Schwall, Institute for Oriental and European Archaeology, Austrian Academy of Sciences, Hollandstrasse 11-13, 1020, 1010 Vienna, Austria, christoph.schwall@oeaw.ac.at

Tatjana M. Gluhak, Römisch-Germanisches Zentralmuseum Mainz, Ernst-Ludwig-Platz 2, 55116 Mainz, Germany; gluhak@rgzm.de

\section{Introduction}

This contribution focuses on the volcanic rock grinding stones brought to light during the excavations conducted by the German Archaeological Institute (DAI) at the Greek colony Selinunte on Sicily. Close examination of these grinding stones provides an opportunity to present new data concerning the development of milling techniques, as well as the opportunity to explore the systems of rock procurement of a Greek colony in the central Mediterranean. Sicily, in particular, offers important insights for the development of two different milling techniques. Firstly, in the 5th century BC, the so-called 'Olynthian' or 'Olynthus' mill was known throughout the eastern Mediterranean Basin and can be interpreted as an advanced grinding mechanism (Frankel 2003, 7; 2007, 222, fig. 15; Alonso and Frankel 2017, 466-67). Secondly, the oldest known circular rotary mills found in the western Mediterranean and dated to the 5th century or possibly the end of the 6th century BC (Alonso 1995; 1996; 1997; Alonso and Frankel 2017, 46772). The latter mills driven with a rotary motion became common for grain milling during the Roman period throughout the entire Mediterranean as well as in the Roman provinces (Runnels 1981, 128; Mangartz 2008, 192-94; Schaaff 2010, 268-69; Wefers 2012a, 90-95). With regard to the occurrence of these new milling techniques, the grinding stones of Selinunte are of particular interest as they hail from well stratified 6th-century BC contexts and provide new data regarding the debate concerning the development of milling (Wefers 2011, 67-69; $2012 \mathrm{a}, 87-90 ; 2012 \mathrm{~b})$. In addition, geochemical and petrographical analyses of these artefacts allow us to identify rock procurement systems and trading activities by this central Mediterranean Greek colony. 


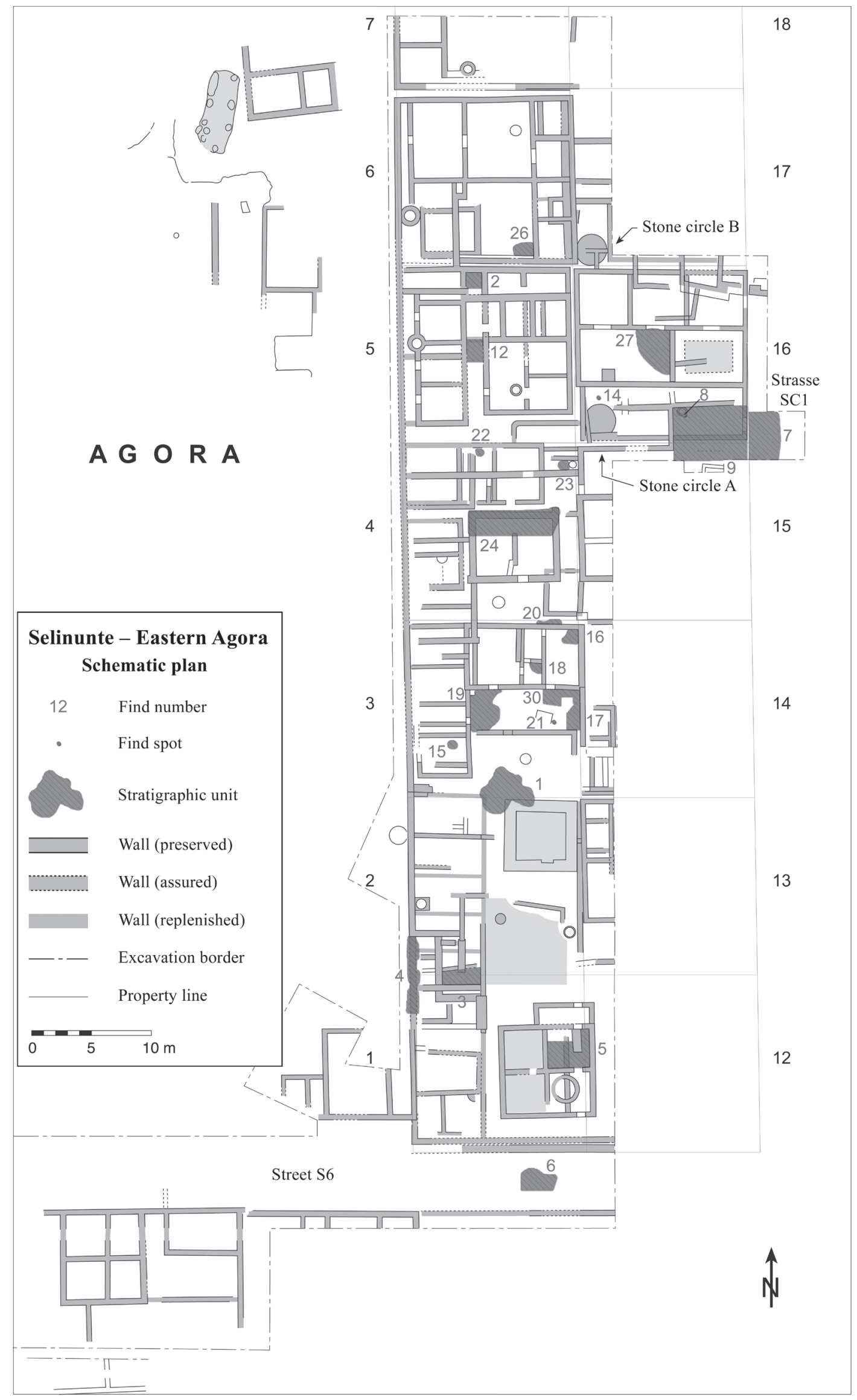

Fig.1: Excavation plan of the eastern area of the Agora with the find spots of the grinding stones and pounders (map basis: German Archaeological Institute, Rome Department, Excavation Selinunte). 


\section{The grinding stone assemblage}

Thirty-one stone tools, primarily volcanic rocks, linked to grain processing were collected during the excavations undertaken by the DAI at the Agora of Seliunte in campaigns between 1996 and 2005. Most were discovered in the eastern area of the Agora (Fig. 1). The majority (26) are saddle querns (nos. 3-4., 6-22, 24a/b-27, 29-30) ${ }^{1}$. The others include four pounders (nos. 2, 5, 23 and 28) and one unidentified stone (no. 1) most likely for crushing grain ${ }^{2}$.

Almost all, except the three pounders and three upper stones of grinding stones ${ }^{3}$, are fragments and the find spot of most cannot be linked to their original function. They were found in secondary position mainly as building material for pavements and streets (nos. 6 and 23) or in the filling of levels of levelling (nos. 1-5, 10, 12-13, 15-20, 24a/b-25, 2830). Two of the three complete saddle querns (Fig. 2) were found in potential grain processing contexts, whereas the third (Fig. 3, no 13) was in the backfill
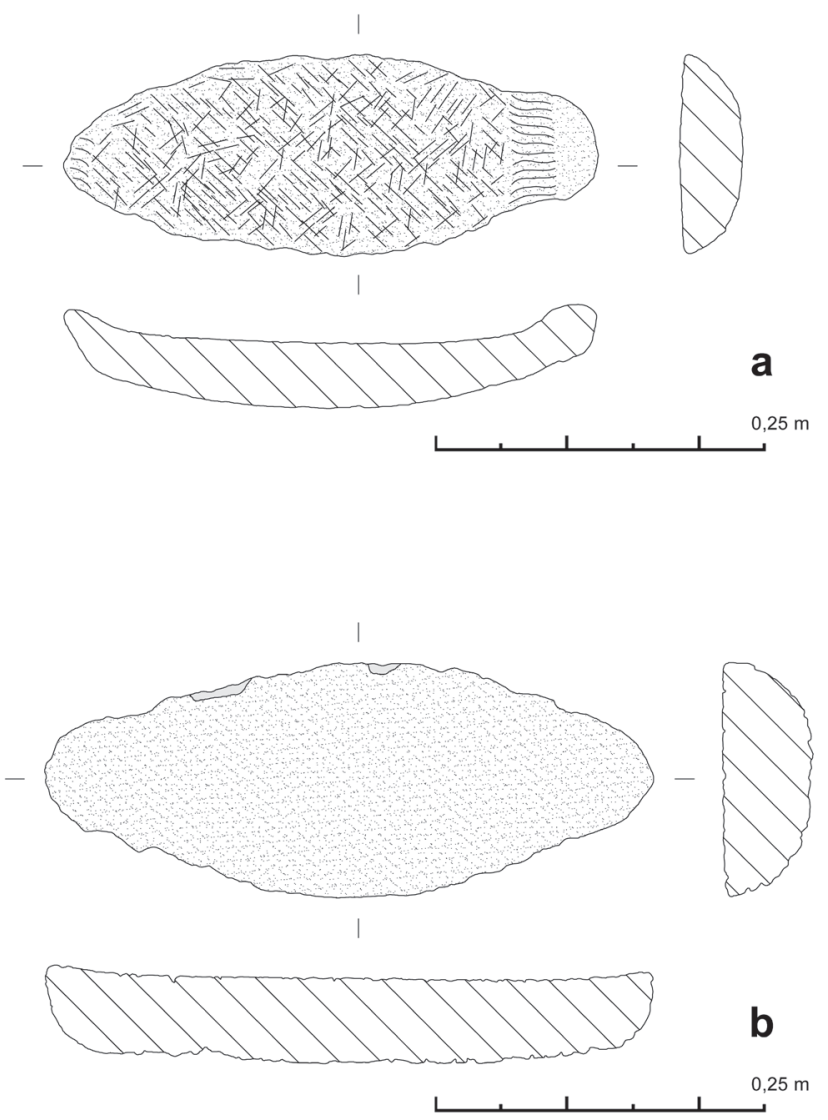

Fig. 2a-b: Boat-shaped upper stones excavated in the eastern area of the Agora of Selinunte.

1. Two fragments ( $a$ and $b$ ) of a single saddle quern are attributed to no. 24 because they come from different stratigraphic units.

2. In addition to grinding organic or inorganic materials, pounders also served to fashion the querns and peck their working surfaces ( $c f$. Graefe 2009, 91-92).

.3 Pounders, nos. 2, 5 and 28; saddle querns: nos. 13-14 and 21 (cf. no. fig. 1). of a hole cut into the bedrock ${ }^{4}$. One saddle quern grinding stones (Fig. 2b, no. 14) was found in a shallow layer next to a cooking pot in a partially paved horizon (Fig. 4) indicating a use related to food processing. The other (Fig. 2a, no. 21) was beside a razed hearth and next to two subsequent hearths (Fig. 5) indicating that this sector of the building served for food production in subsequent horizons.

In general it is the upper stones (19 examples) that reveal typological features. Only two of three lower stone fragments can be attributed to roughly rectangular slabs (nos. 19 and 25). Upper stones are characterised by an oval, elongated, boat-shape. Only one case is nearly oval and narrows slightly in the middle with two appendages which can be interpreted as handle grips (Fig. 3). The wear of the boat-shaped upper stones clearly reveal their function (Fig. 2a). This type, in fact, represents the majority of the finds discussed in this paper. Their dimensions range from $40-50 \mathrm{~cm}$ in length, $15-20 \mathrm{~cm}$ in width, and $6-10 \mathrm{~cm}$ in thickness. Due to the poor state of preservation of the lower stones it was only possible to measure a maximum thickness of up to $8 \mathrm{~cm}$.

Regarding the chronology (cf. Table 1), 12 of the 31 finds (nos. 3, 12-13, 15, 18-23, 26 and 30) can
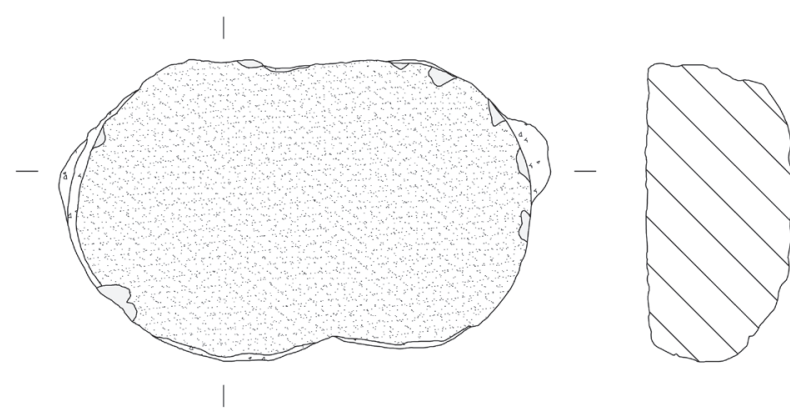

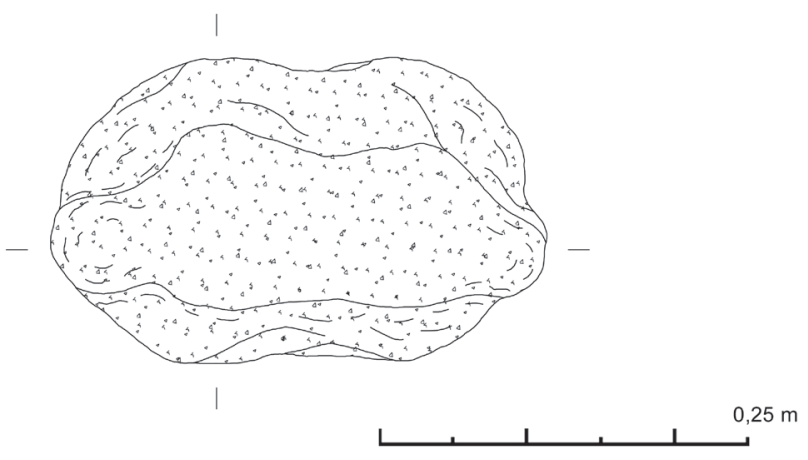

Fig. 3: Upper stone with grips from the north-western area of the Agora of Selinunte.

4. No. 13. The nature (upper or lower stone) of five poorly preserved fragments cannot be determined (nos. 6, 9-10, 22, 29). 


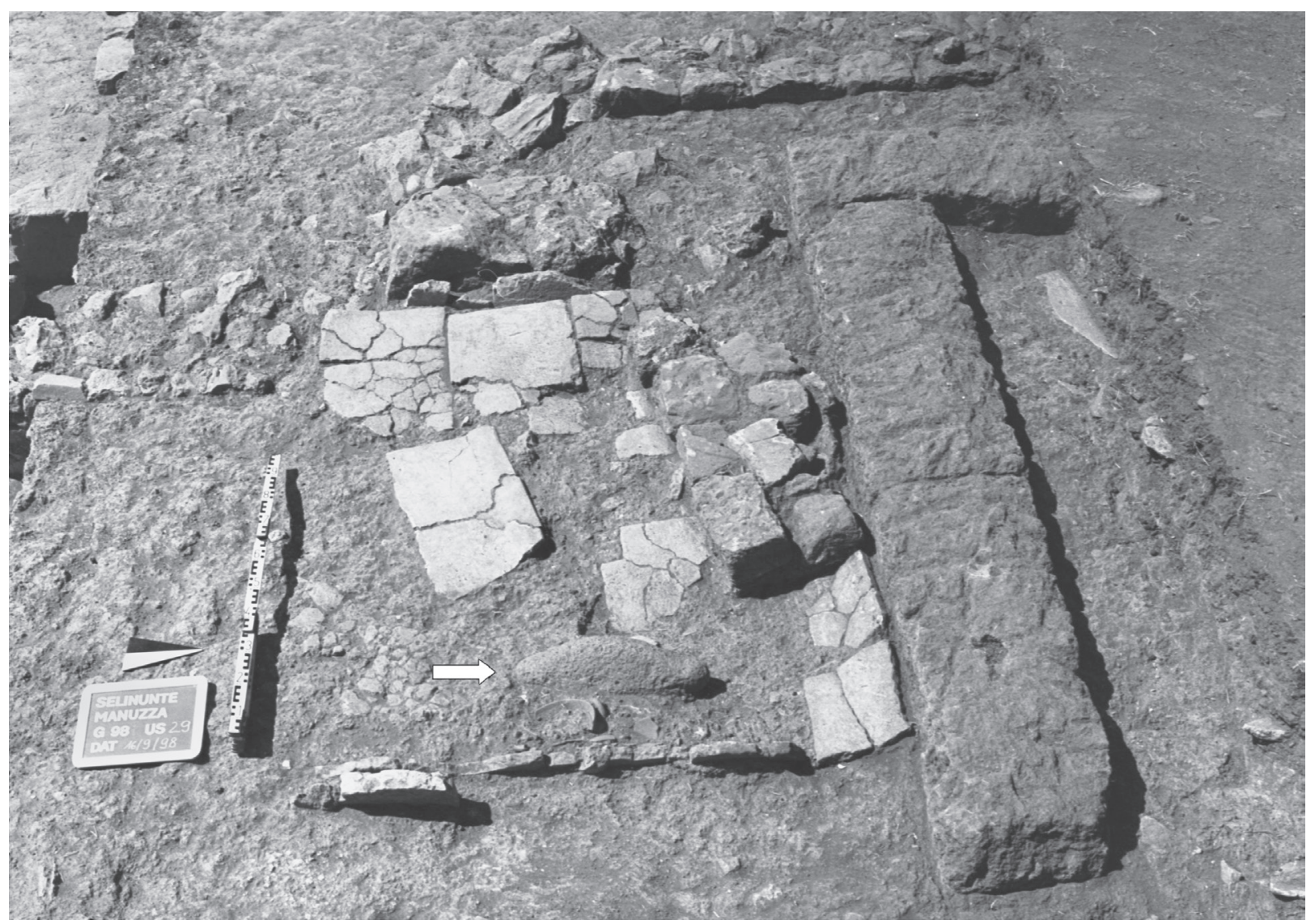

Fig. 4: Find spot of a boat-shaped upper stone of a quern (no. 14; cf. fig. 2b) next to a cooking pot (photo: German Archaeological Institute, Rome Department, Selinunte Excavation).

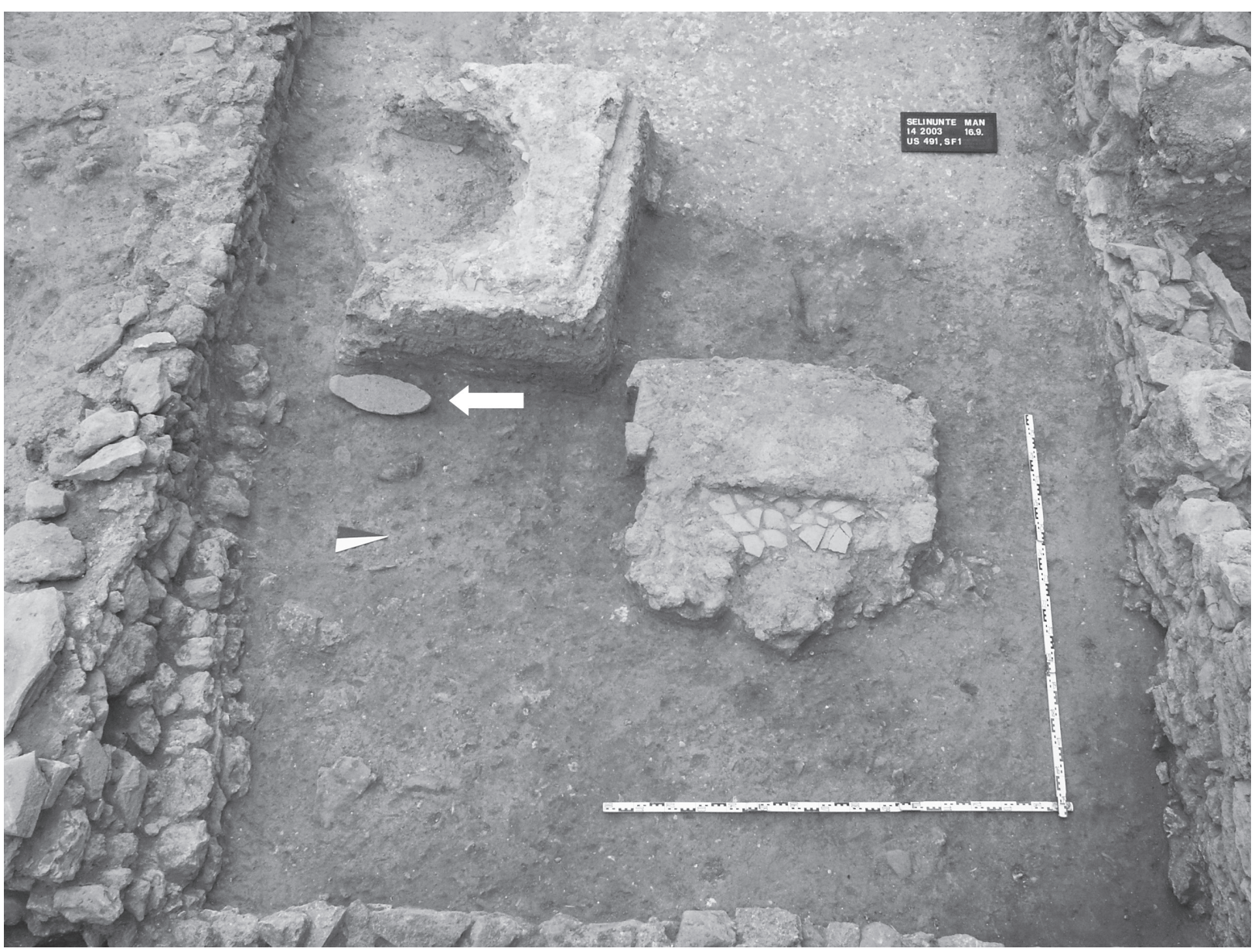

Fig. 5: Find spot of a saddle quern (no. 21; fig. 2a) close to hearths of different horizons (photo: German Archaeological Institute, Rome Department, Selinunte Excavation). 


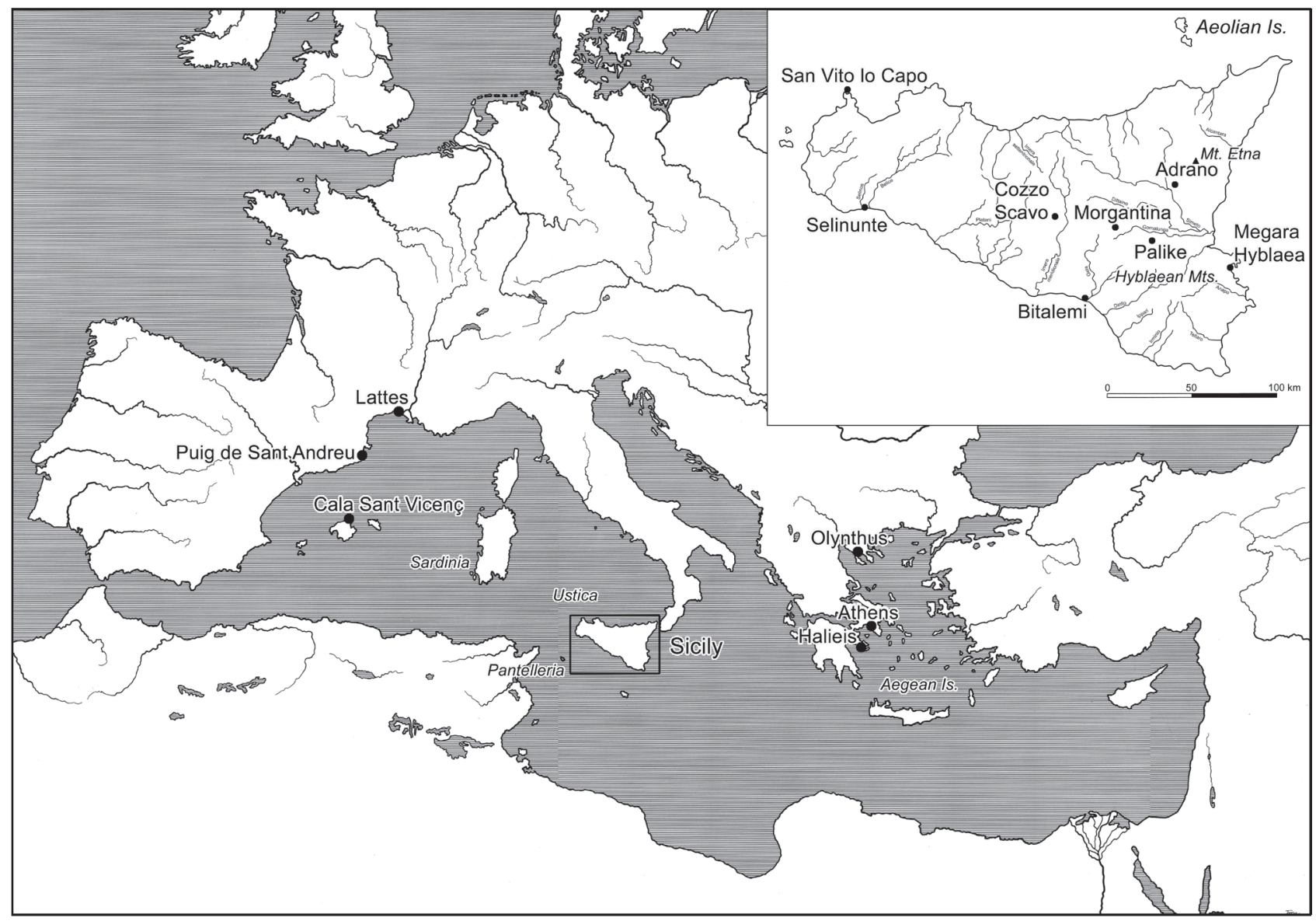

Fig. 6: Map indicating the geographical regions cited in the text and sites with similar boat-shaped saddle querns.

be assigned to the 6th century BC. Nine examples (nos. 1-2, 4-5, 8, 10, 14, 17, 24b) fall between the 4th and 3rd century BC, three (nos. 16, 24a and 27) were collected in clear contexts from the 6th to 5 th/4th century BC, and two (nos. 28-29) from medieval layers and only five (nos. 6-7, 9, 11 and 25) are not dated. Correlating the different shapes with their particular dating, it becomes clear that the boat-shaped upper parts of the saddle querns are prevalent in the 6th century BC.

\section{Boat-shaped saddle quern parallels}

Saddle querns like those found at Selinunte are common in Sicily as well as other sites in the Mediterranean (Fig. 6). They are present in both western and eastern Sicily such as at Morgantina (Prov. Enna; White 1963, 201-202, pl. 47, 3-4), in the vicinity of Mount Etna (stored in the Museo Archeologico Etneo in Adrano, Prov. Catania; Franco 1969, 45-46, fig. 1), in the sanctuary of Palike near Rocchicella (Prov. Catania; Randazzo 2008, 290, fig. 160, 362) and from the presumed shipwreck close to San Vito lo Capo (Prov. Trapani; Rocca 2006, 8-11). Similar upper stones are also known at the sanctuary of Bitalemi near Gela (Prov. Caltanissetta; Orsi 1906, 591-92, fig. 400), at Megara Hyblaea (Prov. Siracusa; Gras et al. 2004, 115, fig. 11) and at Cozzo Scavo near Caltanissetta (Prov. Caltanissetta; Amata et al. 1994, 228, fig. 2,A; Modeo 2006, 249, no. 3748). This type of boat-shaped upper stone is also known along the north-eastern coast of Spain such as at Puig de Sant Andreu close to Ullastret (Prov. Girona; Genís 1986, 107; 110; Portillo 2006, fig. 29.1-7) where it is coupled with rectangular lower stones. A similar coupling is interpreted for the finds of the shipwreck of Cala Sant Vicenç near Pollença (Prov. Islas Baleares; Vivar Lombarte 2006, 260-61) off the northern coast of Mallorca and for certain stones recovered at Lattes (Dépt. Hérault; Py 1992, 185) along the southern coast of France. In the eastern Mediterranean, boat-shaped saddle querns are found at the Greek sites Olynthus (Per. Kentriki Makedonia; Robinson 1930, 70-71; Robinson and Graham 1938, 326-27, pl. 79,1-7; Moritz 1958, pl. 2c), Athens (Per. Attiki; Runnels 1981, 117-19, 340, fig. 24, ST 255; pl. 19, ST 692) and Halieis (Per. Peloponnisos; Runnels 1981, 117-119, 338, fig. 22, HS 395; 339, fig. 23, HS 396). The type of quern consisting of boat-shaped upper stone coupled with a roughly rectangular lower stone is evidenced by recent finds from Selinunte's pottery district (Insula S 16/17-E) (Bentz et al. 2013, 79, fig. 6)

5. We thank Prof. Dr. M. Bentz and J. M. Müller M.A. (University of Bonn) for providing detailed information and unpublished photographs of these recent finds. 
The shape, the traces of wear and the dimension of these finds confirm that boat-shaped upper stones were coupled with rectangular lower stones ${ }^{6}$.

Furthermore, comparable saddle querns from eastern and western Mediterranean are dated between the 7th and 3rd century BC, a chronological range that corresponds to the saddle querns from Selinunte.

\section{Evidence concerning the development of grinding mechanisms}

Despite the absence of Olynthus mill and mills driven with a rotary motion among the recent finds from the Agora, both types are known elsewhere at Selinunte, notably at the Acropolis ${ }^{7}$.

An early grinding development is the coupling of boat-shaped upper stones, at times with grips, with rectangular lower stones (Fig. 7b), a system already in place during the 6th century BC that represents an advancement over the earlier saddle quern (Fig. 7a). The presence of grips indicates they were driven by hand with a to-and-fro movement in a kneeling position.

A subtype of the elongated upper stone, with two grips and a central hopper (Fig. 7c), presumably originating in the Eastern Aegean or Western Anatolia (Moritz 1958, 42-43; Frankel 2003, 8, 18; Lucas 2006, 11), appears to be a prototype of the Olynthus mill (Fig. 7d).

The more efficient Olynthus mill, characterised by its central hopper which allowed grains to be fed in during the grinding process and operated by a lever with the person in a standing position ( $c f$. Frankel 2003, 2-8) ${ }^{8}$, ultimately became widespread and dominated in the eastern Mediterranean. The earlier type coupling a boat-shaped upper stone and a rectangular lower stone (Fig. 7b) therefore represents a 'technical link' to the later Olynthus mills.

\section{Summary of the results of the provenance analyses}

The geochemical major and trace element compositions revealed by WDXRF spectrometry for the provenance of 22 grinding stones, undertaken by Gluhak and Schwall (2015), indicate that the volcanic rocks come from different geodynamic

6. Cf., for example, Robinson 1930, 70-71; Robinson and Graham 1938, 326-27; White 1963, 202; Vivar Lombarte 2006, 260-61.

7. Several upper and lower stones of saddle querns, Olynthus mills and the lower stone of a Morgantina mill were found in the southern area of the Acropolis ( $c f$. White 1963, 202-04) in a room near the Corpo di Guardia (GPS coordinates: N 37.58212 ${ }^{\circ}$, E 12.82545 ${ }^{\circ}, 31.05 .2011$; $c f$. Helas $2011,100)$. Since the precise contexts were not recorded, they can only be dated by the termius ante quem corresponding to the abandonment of Selinunte during the First Punic War (250 BC).

8. A different use has been suggested by J. ChausserieLaprée (1998, 229, fig. 17) based on finds at Martigues on the southern coast of France.

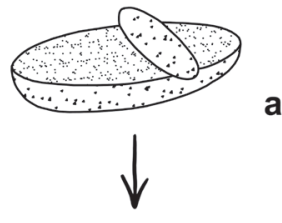

common form of saddle quern

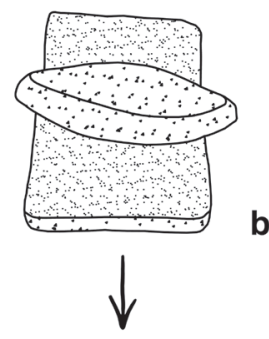

advanced form of saddle quern with rectangular lower stone

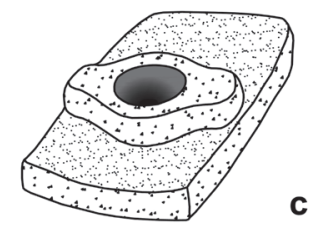

Olynthus mill with hand grips and hopper

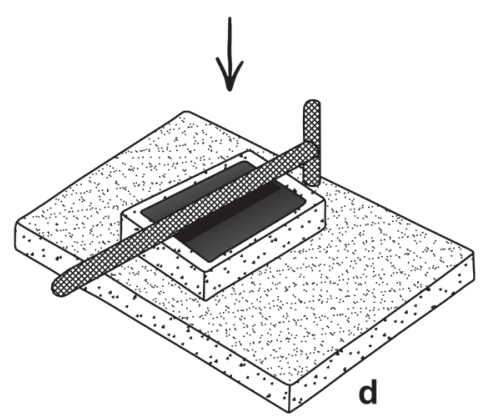

Olynthus mill operated with a lever

Fig. 7a-d: Schema of the typological development of grinding mechanisms (drawings by $\mathrm{Ch}$. Sshwall based on 7a, d: Mangartz 2008, 25, fig. 4; 7b: Genís 1986, 107, fig. 4; 7c: Lucas 2006, 12, fig. 1.3).

settings. The Mediterranean region has a complex geological history with a number of varying geodynamic settings (for a detailed presentation and discussion see Lustrino and Wilson 2007 and Lustrino et al. 2011) that result in volcanic rocks with different compositions. It is the study of the compositions that is the key to unravelling their origin. This methodology is described in detail in Gluhak and Schwall (2015).

An origin from the Hyblean Mountains in southeastern Sicily was established for stones 17, 20, and 26 while nos. 2, 9, 14, 27, 29, by contrast, are linked to Mt. Etna/Mongibello in the north-west of the Sicily. The compositions of stones 4, 6, 7, 8, $10,11,12,16,18,19,21,23,24 \mathrm{a} / \mathrm{b}, 25$ strongly correlate with the Aeolian Islands indicating these islands could be the source. However, the exact location of the source in the Aeolian archipelago cannot be determined due to the similarity in the rock formations of the different islands. Furthermore, on the basis of the geochemical data alone, it is not possible to completely exclude the possibility that at least some of the grinding stones were imported from the Aegean, especially taking into account the exchanges between the Greek colony 
Table 1: Provenance of the analyzed grinding stones as determined by Gluhak and Schwall (2015).

\begin{tabular}{|c|c|c|c|}
\hline Dating & Provenance & $\begin{array}{c}\text { Object / Sample } \\
\text { no. }\end{array}$ & Tool \\
\hline $6^{\text {th }}$ century BC & Aeolian Islands? & 12 & saddle quern (upper stone) \\
\hline $6^{\text {th }}$ century BC & Aeolian Islands? & 18 & saddle quern (upper stone) \\
\hline $6^{\text {th }}$ century BC & Aeolian Islands? & 19 & saddle quern (lower stone) \\
\hline $6^{\text {th }}$ century BC & Aeolian Islands? & 21 & saddle quern (upper stone) \\
\hline $6^{\text {th }}$ century BC & Aeolian Islands? & 23 & pounder \\
\hline $6^{\text {th }}$ century BC & Hyblean Mountains & 20 & saddle quern (upper stone) \\
\hline $6^{\text {th }}$ century BC & Hyblean Mountains & 26 & saddle quern (upper stone) \\
\hline $6^{\text {th }}-5^{\text {th }} / 4^{\text {th }}$ century BC & Aeolian Islands? & 16 & saddle quern (upper stone) \\
\hline $6^{\text {th }}-5^{\text {th }} / 4^{\text {th }}$ century BC & Aeolian Islands? & $24 \mathrm{a}$ & saddle quern (upper stone) \\
\hline $6^{\text {th }}-5^{\text {th }} / 4^{\text {th }}$ century BC & Mt. Etna & 27 & saddle quern (upper stone) \\
\hline $4^{\text {th }} / 3^{\text {rd }}$ century BC & Aeolian Islands? & 4 & saddle quern (upper stone) \\
\hline $4^{\text {th }} / 3^{\text {rd }}$ century BC & Aeolian Islands? & 8 & saddle quern (upper stone) \\
\hline $4^{\text {th }} / 3^{\text {rd }}$ century BC & Aeolian Islands? & 10 & saddle quern (?) \\
\hline $4^{\text {th }} / 3^{\text {rd }}$ century BC & Aeolian Islands? & $24 \mathrm{~b}$ & saddle quern (upper stone) \\
\hline $4^{\text {th }} / 3^{\text {rd }}$ century BC & Mt. Etna & 2 & pounder \\
\hline $4^{\text {th }} / 3^{\text {rd }}$ century BC & Mt. Etna & 14 & saddle quern (upper stone) \\
\hline $4^{\text {th }} / 3^{\text {rd }}$ century BC & Hyblean Mountains & 17 & saddle quern (upper stone) \\
\hline Medieval times & Mt. Etna & 29 & saddle quern (?) \\
\hline Undated & Aeolian Islands? & 7 & saddle quern (upper stone) \\
\hline Undated & Aeolian Islands? & 11 & saddle quern (upper stone) \\
\hline Undated & Aeolian Islands? & 25 & saddle quern (lower stone) \\
\hline Undated & Mt. Etna & 9 & saddle quern (?) \\
\hline Undated & Aeolian Islands? & 6 & saddle quern (?) \\
\hline
\end{tabular}

of Selinunte and the Greek mainland. The Aegean Sea, as well as the Tyrrhenian Sea, is strongly influenced by subduction, and its volcanism shows great geochemical uniformity. Neither major nor trace element compositions allow a clear distinction between the volcanic rocks of the Tyrrhenian and Aegean Islands. The results of the provenance analyses are compiled in Table 1.

\section{Provenance and procurement systems}

With the exception of one sample (no. 6), the source of all the grinding stones of Selinunte can be determined with a relative degree of precision. Besides local Sicilian volcanic sources at the Mount Etna (5 samples) and the Hyblean Mountains (3 samples), 13 are presumably from the volcanic outcrops of the Aeolian Islands to the north-east or possibly the Aegean Islands. It must be highlighted, nonetheless, that the source cannot be definitely provenanced due to the issues advanced above.

It is therefore of note that the majority of the sampled stones come from external rock sources, beyond Sicily. Five of the seven sampled grinding stones dated to the 6 th century BC, can be sourced either to the Aeolian or the Aegean Islands. Only two saddle querns of these early stones are from volcanic rocks from the Hyblean Mountains. Exploitation of the Hyblean Mountains is not surprising due to its proximity with the settlement of Megara Hyblaea, the mother colony of Selinunte, on the eastern coast of Sicily.

Of particular interest is the absence of stone imports at Selinunte from the western volcanic sources such as Ustica, Pantelleria and Sardinia (cf. Mangartz 2008, 202-04), outcrops that were intensively exploited for millstones later during the Roman period. Factors such as of the quality and accessibility of the raw material or the expansion of the Punic sphere of interest to western and north-western Sicily could be behind the absence of these imports in the 6th century $\mathrm{BC}^{9}$.

9. Provenance studies of contemporary finds from Greek and Punic colonies as well as indigenous settlements in Sicily would be valuable to verify this hypothesis. At the moment the only published data are from the indigenous Sicilian sites of Monte Castellazzo di Poggioreale (Ferla et al. 1984; Spatafora 1993), Rocca di Entella (Daniele 1997; 1999; Canzanella 1997), and Morgantina (Santi et al. 2015). 
Based on finds like imported amphorae, intensive trade links dating to at least the first half of the 6th century BC are evident with the Greek mainland, the Eastern Aegean and colonies of Magna Graecia. Punic pottery, on the other hand, is rare in the eastern area of the Agora of Selinunte (Dehl-von Kaenel 2003) ${ }^{10}$. Nevertheless, Sicily's strategic position seems to have favoured trans-Mediterranean trade. In this context, F. de Angelis assumes the existence of trade with the Greek mainland and that cereals were important exchange goods for Selinunte at least since the 5th century BC (2003, 194-95). Archaeobotanical studies have revealed that the agricultural conditions in the interior of Sicily, as opposed to the coastal hinterland of Selinunte, were favourable to grain cultivation (Stika et al. 2008, 147). Possible connections to indigenous settlements in Selinunte's hinterland are suggested by two saddle querns recovered during the excavations at the Monte Castellazzo di Poggioreale (Ferla et al. 1984, 46-47, 50; Spatafora 1993, 169). Both are dated to the early 6th century BC and are of volcanic rock from eastern Sicilian sources. It is, however, questionable whether these stones reached the settlement by maritime or land routes.

\section{Conclusions}

To conclude, the assemblage of volcanic grinding stones from the Greek colony of Selinunte indicate provenance from local insular sources as well as longer distance (probably Aeolian or possibly Aegean Islands) outcrops exploited as early as the 6th century BC. The position of Selinunte on the coast would have favoured maritime exchange of volcanic rocks and other products. Therefore it can be assumed that indigenous settlements supplied the Greek colony with grain for its own needs as well as for trade. This could also explain the presence of Greek imports found at the indigenous settlements. Hence it is evident that Selinunte served as an important trading post in the central Mediterranean region for a number of goods including basic mechanisms such as volcanic saddle querns.

\section{Acknowledgements}

The authors would like to thank the colleagues of the Römisch-Germanisches Zentralmuseum Mainz, the German Archaeological Institute, Rome Department, Excavation Selinunte, the Soprintendenza per i Beni culturali ed Ambientali di Trapani and the Archaeological Park of Selinunte for their support during this research project. Special thanks for annotations, suggestions and constructive criticism go to Dr. Holger Baitinger,

10. This picture is also bolstered by pottery finds in the Sanctuary of Malophoros at Selinunte ( $c f$. Dehl-von Kaenel 1995; Kerschner 2000, 490-91).

11. F. de Angelis assumes that trading with the Greek mainland existed and that cereals were important goods for Selinunte at least since the 5th century BC $(2003,194-95)$.
Dr. Christiane Dehl-von Kaenel, Dr. Holger Schaaff, Dr. Andreas Thomsen and especially Dr. Stefanie Wefers. Furthermore we are grateful to Alexandra Plumhoff, B. Sc. (University of, Mainz), for the preliminary results of thin-section studies.

\section{Bibliography}

Alonso, N., 1995. Les premières meules rotatives manuelles dans le nordest de la Péninsule Ibérique. In M.-C. Аmouretti and G. Comet (eds), La transmission des connaissances techniques. Actes des tables rondes d'Aix-en-Provence, avril 1993 à mai 1994, Cahiers d'histoire des techniques, 3, Aix-en-Provence, 15-23.

Alonso, N., 1996. Els molins rotatius. Origen i expansió en la Mediterrània Occidental, Revista d'Arqueologia de Ponent, 6, 183-98.

Alonso, N., 1997. Origen y expansion del molino rotativo bajo en el Mediterraneo occidental. In D. MeEKs and D. GARCIA (eds), Techniques et economies antiques et médiévales. Le temps de l'innovation, Colloque international (C.N.R.S.) d'Aix-en-Provence, 22.-23. mai 1996, Paris, 15-19.

Alonso, N. and Frankel, R., 2017. A survey of ancient grain milling systems in the Mediterranean. In G. Fronteau, S. Lepareux-Couturier and O. Buchsenschutz (eds), Les meules du Néolithique à l'époque médiévale: technique, culture, diffusion. Actes du 2ème colloque du Group Meule, Reims, du 15 au 17 mai 2014, Revue Archéologique de l'Est Supplement, 43, Dijon, 461-78.

Amata, S.M., Fariselli, A. and Panini, R., 1994. Cozzo Scavo (Caltanissetta). Rapporto preliminare della campagna di scavo 1993, Ocnus, 2, 227-32.

Bentz, M., Adorno, L., Albers, J., Müller, J. M. and Zuchtriegel, G., 2013. Das Handwerkerviertel von Selinunt. Die Töpferwerkstatt in der Insula S 16/17-E. Vorbericht zu den Kampagnen 2010-2012, Mitteilungen des Deutschen Archäologischen Instituts, Römische Abteilung, 119, 69-98.

Canzanella, M.G., 1997. Per uno studio della cultura materiale: Le macine di Entella. In Centro Studi e Documentazione sull'Area Elima (ed.), Atti delle I Giornate Internazionale di Studi sull'Area Elima. Gibellina, 22-26 ottobre 1994, Pisa, 251-90.

Chausserie-Laprée, J., 1998. Les meules des habitats protohistoriques de Martigues, Documents d'Archéologie Méridionale, 21, 211-35.

Daniele, D., 1997. Studio chimico-petrografico e individuazione delle aree di provenienza del materiale lavico delle macine di Entella. In Centro Studi e Documentazione sull'Area Elima (ed.), Atti delle I Giornate Internazionale di Studi sull'Area Elima. Gibellina, 22-26 ottobre 1994, Pisa, 465-524. 
Daniele, D., 1999. Le macine laviche di Entella in Sicilia. Studio chimico-petrografico finalizzato alla determinazione della provenienza. In C. D'Aмісо and $\mathrm{C}_{\mathrm{H}}$. TAmpellini (eds), Le Scienze della terra e l'archeometria - 5a giornata. Bari, 19-20 febbraio 1998, Bologna, 89-95.

De Angelis, F., 2003. Megara Hyblaia and Selinous. The Development of Two Greek City-States in Archaic Sicily, Oxford University School of Archaeology Monographs, 55, Oxford.

Dehl-von Kaenel, CH., 1995. Die archaische Keramik aus dem Malophoros-Heiligtum in Selinunt. Die korinthischen, lakonischen, ostgriechischen, etruskischen und megarischen Importe sowie die 'argivisch-monochrome' und lokale Keramik aus den alten Grabungen, Berlin.

Dehl-von KaENEL, CH., 2003. Transportamphoren aus der Ladenzeile. In D. Mertens, Die Agora von Selinunt. Neue Grabungsergebnisse zur Frühzeit der griechischen Kolonialstadt, Mitteilungen des Deutschen Archäologischen Instituts, Römische Abteilung, 110, 438-45.

Ferla, P., Alaimo, R., Falsone, G. and Spatafora, F., 1984. Studio petrografico delle macine di età arcaica e classica da Monte Castellazzo di Poggioreale (Sicilia occidentale), Sicilia Archeologica, 56, 25-52.

Franco, S., 1969. L'utensilistica litica dei villaggi etnei, Sicilia Archeologica, 8, 1969, 44-50.

Frankel, R., 2003. The Olynthus Mill, Its Origin, and Diffusion: Typology and Distribution, American Journal of Archaeology, 107/1, 1-21.

Frankel, R., 2007. Water Mills in Israel. In J.-P. BRUN and J.-L. Fiches (eds), Energie hydraulique et machines élévatrices d'eau durant l'Antiquité. Actes du colloque international à Vers-Pont-du-Gard, 20-22 septembre 2006, Collection du Centre Jean Bérard, 27, Naples, 215-24.

GENís, M.T., 1986. Cap a una tipologia dels molins d'època ibèrica a Ullastret, Faventia, 8/2, 99-113.

GluhaK, T.M. and Schwall, Ch., 2015. Provenance Analyses of the Volcanic Rock Grinding Stones from the Greek Colony Selinunte, Sicily, Archaeometry, 57/2, 246-68.

Graefe, J., 2009. Neolithische Mahlsteine zwischen Weserbergland und dem Niederrhein. Zur wirtschaftsarchäologischen Aussagekraft einer Fundgruppe, Universitätsforschungen zur prähistorischen Archäologie, 174, Bonn.

Gras, M., Tréziny, H. and Broise, H., 2004. Mégara Hyblaea 5. La ville archaïque. L'espace urbain d'une cite greque de sicile orientale, Roma.

Helas, S., 2011. Selinus II. Die punische Stadt auf der Akropolis, Sonderschriften des DAI Rom, 15, Mainz.
Kerschner, M., 2000. Die bemalte ostgriechische Keramik auf Sizilien und ihr Zeugniswert für den archaischen Handel. In F. KRINZINGER (ed.), Die Ägäis und das westliche Mittelmeer. Beziehungen und Wechselwirkungen 8. bis 5. Jh. v. Chr. Akten des Symposions Wien, 24.-27. März 1999, Archäologische Forschungen, 4, Wien, 487-98.

Lucas, A., 2006. Wind, Water, Work. Ancient and Medieval Milling Technology, Technology and Change in History, 8, Leiden.

Lustrino, M. and Wilson, M., 2007. The circumMediterranean anorogenic Cenozoic igneous province, Earth-Science Reviews, 81, 1-65.

Lustrino, M., Duggen, S. and Rosenberg, C. L., 2011. The Central-Western Mediterranean: Anomalous igneous activity in an anomalous collisional tectonic setting, Earth-Science Reviews, 104, 1-40.

Mangartz, F., 2008. Römischer Basaltlava-Abbau zwischen Eifel und Rhein. Monographien des RömischGermanischen Zentralmuseums, 75 = VulkanparkForschungen, 7, Mainz.

Modeo, S., 2006. Cozzo Scavo. In R. Panvini (ed.), Caltanissetta. Il Museo Archeologico, Caltanissetta, 241-51.

Moritz, L.A., 1958. Grain-Mills and Flour in Classical Antiquity, Oxford.

Orsi, P., 1906. Gela, Scavi del 1900-1905, Monumenti Antichi, 17, 1-758.

Portillo, M., 2006. Mòlta i triturat d'aliments vegetals durant la protohistòria a la Catalunya Oriental, La. Unpublished dissertation, University of Barcelona, viewed 18 December 2018, http://hdl.handle. net/10803/2594.

Py, M., 1992. Meules d'époque protohistorique et romaine provenant de Lattes, Lattara, 5, 183-232.

RandAzzo, M., 2008. I livelli di età classica della stoà B: primi dati sui materiali. In L. Maniscalco (ed.), Il santuario dei Palici. Un centro di culto nella Valle del Margi, Collana d'area, 11, Palermo, 187-203.

Robinson, D.M., 1930. Excavations at Olynthus II. Architecture and Sculpture. Houses and other Buildings, Baltimore.

Robinson, D.M. and Graham, H.W., 1938. Excavations at Olynthus VIII. The Hellenic House. A Study of the Houses Found at Olynthus with a Detailed Account of those Excavated in 1931 and 1934, Baltimore.

RoccA, M., 2006. Indagine preventive sul relitto delle macine. Relazione scientifica. Campo Scuola di Archeologia Subacquea Settembre 2006. San Vito lo Capo (TP), viewed 20 October 2011, 
http://www.regione.sicilia.it/beniculturali/ archeologiasottomarina/sez_campiscuola/ relazione $\% 20$ scientifica\%20macine.pdf.

RunNels, C.N., 1981. A diachronic study and economic analysis of millstones from the Argolid, Greece. Unpublished dissertation, University of Indiana.

Santi, P., Renzulli, A. and Bell, M., 2014. The volcanic millstones from the archaeological site of Morgnatina (Sicily): provenance and evolution of the milling techniques in the Mediterranean area, Archaeometry, 57/5, 803-21.

SchAAFF, H., 2010. Steine für das römische Reich. $\mathrm{Zu}$ den Anfängen des antiken Steinbruch- und Bergwerksreviers zwischen Eifel und Rhein. Archäologisches Korrespondenzblatt, 40, 265-72.

Spatafora, F., 1993. Un gruppo di macine da Monte Castellazzo di Poggioreale. In J. DE La Genière, M.L. Famà, G. Gullini, H.P. Isler, G. Nenci and A. Spanò (eds), Studi sulla Sicilia occidentale in onore di Vincenzo Tusa. Padova, 165-71.

Stika, H.-P., Heiss, A.G. and Zach, B., 2008. Plant remains from the early Iron Age in western Sicily. Differences in subsistence strategies of Greek and Elymian sites, Vegetation History and Archaeobotany, 17 Supplement 1, 139-48.

Vivar Lombarte, G., 2008. Els molins de vaivé. In X. NiEto and M. SAntos (eds), El vaixell grec arcaic de cala Sant Vicenç, Monografies del Centre d'Arqueologia Subaquàtica de Catalunya, 7,Girona, 259-66.

WeFers, S., 2011. Still using your saddle quern? A compilation of the oldest known rotary querns in western Europe. In D. PeAcock and D. Williams (eds), Bread for the people. The Archaeology of Mills and Milling. Proceedings of a colloquium held in the British School at Rome 4th-7th November 2009, British Archaeological Reports. International Series 2274. Oxford, 67-76.

WeFERs, S., 2012a. Latènezeitliche Mühlen aus dem Gebiet zwischen den Steinbruchrevieren Mayen und Lovosice, Monographien des Römisch-Germanischen Zentralmuseums, 95 = Vulkanpark-Forschungen, 9, Mainz.

Wefers, S., 2012b. Reibst Du noch oder drehst Du schon? Die ältesten bekannten Drehmühlen des westlichen Europa. In A. KeRn, J.K. КосH, I. Balzer, J. Fries-Knoblach, K. Kowarik, C. Later, P. C. Ramsl, P. Trebsche and J. Wiethold (eds), Technologieentwicklung und -transfer in der Hallstattund Latènezeit. Beiträge zur Internationalen Tagung $\operatorname{der}$ AG Eisenzeit und des Naturhistorischen Museums, Prähistorische Abteilung - Hallstatt, Beiträge Ur- und Frühgeschichte Mitteleuropas, 65. Langenweißbach, 13-24.

White, D., 1963. A Survey of Millstones from Morgantina, American Journal of Archaeology, 67, 199-206. 